В България не е популярна практиката за извънсъдебно уреждане на спорове.

\section{Обсъжаане}

Броят на жалбите, отправяни към дадена институция, най-вероятно се влияе от доверието към нея, но и от проблемите в сектора, за който се отнасят. Ето защо се предполага, че те представят сравнително достоверно дефицитите и потребностите от корекции от гледна точка на пациентите, а смисъльт е да се реши не просто личният проблем, засягащ жалбата, а да се превантират следващи подобни проблеми и взаимоотношения. Броят на жалбите и сигналите на граждани за проблеми в здравната система (2772 броя), отправени към Омбудсмана имат трайна тенденция на нарастване [2]. Структурата на проблемите показва устойчивост през целия дванадесетгодишен период от съществуването на институцията на Омбудсмана по отношение на теми като достьп и качество на медицинската помощ (МП) и проблемите на трудовата експертиза. Същото се установява и при ИАМО, както и при КЗД $[1,3]$.

Съдебните решения, засягащи взаимоотношенията в българската здравна система са малко на брой, най-вероятно поради много фактори, включително финансови, забавяне във времето, съмнение в експертизата и обективността и т. H. [6].

\section{Изводи}

Пациентите имат нагласа за защита на собствените и на своите близки интереси в областта на медицинското обслужване и медицинското право. Нараства броят на подаваните сигнали и това е трайна тенденция. Дори и след извършена проверка от компетентните институции и органи, те се интересуват от резултатите, от констатациите, от наложените санкции и нерядко - макар и понякога чисто субективно, се обръщат за повторна проверка.
Сигналите за неудовлетвореност от качеството на оказаната медицинска помощ през целия анализиран период съставляват 60-70\% от всички жалби към обследваните компетентни органи, получаващи жалби и сигнали. Проблемът с оценка на качеството на медицинската помощ изисква целенасочени действия от компетентните органи (Министерство, съсловни организации, научни дружества).

Може да се приеме, че анализът на подаваните жалби достоверно отразява проблемите в здравната система през погледа на пациентите, като броят на жалбите и сигналите, тяхната допустимост, но и дельт на неоснователните такива са различни при различните институции и зависят от тяхната способност за експертиза, компетентности и правомощия.

Съдебните решения, засягащи взаимоотношенията в българската здравна система, са малко на брой, най-вероятно поради много фактори, включително финансови, забавяне във времето, съмнение в експертизата и обективността, но също имат тенденция да растат.

\section{Библиография}

1. Годишни отчети за дейността на КЗД 2005 - 2017г., www.kzd- nondiscrimination.com

2. Годишни отчети за дейността на Омбудсмана на Р. България 2005 2017 г, www.ombudsman.bg/dokuments/gd

3. Годишни отчети за дейността на ИАМО 2012-2017г., eama.bg

4. Отговор на запитване до КЗД относно сигнали и жалби, отправени към КЗД във връзка с проблеми в здравната система за периода 2005 -2017г., 60-00-99от 10. 09. 2018 г.

5. Илиева А., Контрольт в здравеопазването, Сиела, 2018, ISBN 978954-28-2541-8

6. Шаркова М., Медицинският деликт, под редакцията на Д. Доковска, 2018

7. Gostin L. O.,The Right to Health:A Right to the Hghest Attainable Standarts of Health.HASTINGS CENTER REPORT 29-109(2001)

8. Swendiman K. S. Health Care: Constitutional Rights and Legislative Powers, Juli 9,2012

\title{
нови КнИгИ
}

\section{Хеморагичната треска с бъбречен синдром и Кримско-Конго хеморагична треска М. Пишмишева, И. Христова, Н. Ватев, изд. Изток/Запад, 2018, 138 с.}

Интересът към вирусните хеморагични трески не стихва поради разширяване на ареалите на разпространение, нарастване на заболяемостта, трудната диагноза и неприемливо високия леталитет. Тези заболявания са природно-огнищни, транмисивни зооантропонози, с ограничени ареали на разпространение. Нашата страна е ендемична за Хемогагичната треска с бъбречен синдром и Кримска-Конго хеморагична треска. Проучвания върху тези заболявания започват в средата на миналия век и българската наука има традиции и принос в проучванията на двете заболявания. Настоящата монография е логично и достойно продължение на научните търсения, и обобщение на постигнатото в познанията за вирусните хеморагични трески. Авторите предлагат съвременни данни за епидемиологията на тези тежки инфекции, нови данни за разпространението им у нас, в съседните страни, в Европа и света. Изключително важни са данните за възможностите на съвременната диагностика, която у нас тя се извършва от Националната референтна лаборатория по предавани с кърлежи патогени към НЦЗПБ, осигуряваща ранна диагноза на вирусните хеморагични трески. Монографията включва и практически препоръки за коректно набиране и транспорт на биологичните материали, детайлна клинична характеристика на тези заболявания и възможните терапевтични алгоритми. Обобщени са специфичните и неспецифични профилактични мероприятия - ефективни ваксини за имунопрофилактика, контрол върху популацията на гризачите и дезакаризационните мероприятия в природните огнища, обезкърлежаване на домашните животни и спазване на строг противоепидемичен режим при обслужване на болни. Монографията представлява едно съвременно ръководство за диагностика, терапия и превенция на Хемогагичната треска с бъбречен синдром и Кримска-Конго хеморагична треска. Книгата е адресирана към студенти и общопрактикуващи лекари, към инфекционисти, епидемиолози, вирусолози и други специалисти. Предоставената от авторите информация е значима, тъй като епидемиологичните данни са едни от опорните пунктове за ранната, коректна диагноза и свързаната с нея терапия и превенция на разпространението.

Из реценцията към монографията проф. д-р Мария Стойчева, ръководител катедра по инфекциозни болести, паразитология и тропическа медицина, МУ - Пловдив 